\title{
WHAT COLOR IS THE WHITE HOUSE? OR JOURNALISM IN THE POST-TRUTH ERA INTERVIEW WITH PATRICK VISONNEAU
}

\author{
Interview conducted by William F. Cipolla
}

\author{
PATRICK VISONNEAU ${ }^{1} \&$ WILLIAM F. CIPOLLA ${ }^{2}$ \\ ${ }^{1}$ Former News Director, France 3, Nord Ouest, retired. \\ 2 St. John's University, 8000 Utopia Parkway, Queens, New York 11439, USA. ORCID: 0000-0002-0311- \\ 3268,Email:wfcipolla@optimum.net
}

The following interview took place during the conference Truth and Communication in the Era of Misinformation from Kierkegaard to Social Media held at St. John's University, November 16-17, 2018.

CIPOLLA: It is a great pleasure for me to introduce my friend Patrick Visonneau. Patrick has had a long and distinguished career in journalism in France where he served as Editor in Chief for Le soir sur la 3 with Christine Ockrent as well as producer for the political broadcasts Dimanche soir (1994-1997) and France Europe Express (1997-1999). He was named News Director for France 3 in 1996 and served as Regional Director of France 3 for Paris and the Ile de France from 2001 until 2010 when he became Director of France 3 Nord Ouest, which covers the six neighboring regions: Paris Ile de France, Brittany, Pays de la Loire, Haute-Normandie, Basse-Normandie and Centre. Patrick has been named Chevalier de l'Ordre National du Mérite for distinguished public service.

CIPOLLA: Your title seems an obvious provocation, Patrick, since everyone knows the answer to that simple-minded question.

VISONNEAU: Well, no, I'm not so sure of that. According to certain eminent scholars the squirrels on the lawn see green; the flies in front of the oval office windows see 
black and, when he watches CNN, Donald Trump undoubtedly sees red. Is it possible, then, that the truth could be a question of point of view?

Now first let me say a word on the expression post-truth era which seems bizarre: a Swiss journalist, Jean Amann considers this expression as 'one more post-something, after post-modernism, post-industrialism, post-structuralism, etc. What was there before the post-truth era? Was it really the era of truth? The era of the Protocols of the Elders of Zion? The War to end all Wars? The Russians calling Stalin le petit père des peoples (the little father of the people)?' Or perhaps Colin Powell's bottle filled with the proof of biological warfare shown to the world at the General Assembly of the United Nations. No, as we have seen, fake news is not a new phenomenon. What is new is this dangerous elixir where emotion, magnification, speed, and information overload meet in an astonishing contemporary cocktail.

CIPOLLA: You have mentioned four different elements in this heady mix. Let's start with the first. What exactly do you mean by emotion in the context of journalism?

VISONNEAU: The great adversary of journalism, the one that privileges fake news, is feeling or emotion. Emotion levels everything, it becomes a parasite on analysis and prevents the journalist from establishing a hierarchy.

CIPOLLA: Can you give us an example?

VISONNEAU: An example? I have a clear memory of two TV news stories, two days apart, in which two reports struck me by their similarity in form and tone but where the essence of the stories was completely and dramatically different. In the first story, a woman in the South of France who had lived through a flood in her town, appears in her kitchen showing, by pointing to a line on the wall, the height the flood water had reached. In tears, after pointing out that all her appliances had been destroyed, she says 'I have lost everything'. In the second story, a woman in Bosnia who lost her husband and her son in the bombing, turns to the camera and says, 'I have lost everything'. Two women use the same words, with the same shattering cry of pain, but for two news items of completely different dimensions. These were two news stories whose goal was to evoke the compassion of the viewers; two stories where emotion dominates reporting, but in which we lose the true sense of value, the loss of a dishwasher as opposed to the loss of a husband and son.

CIPOLLA: Okay, I understand. But hasn’t emotion, always played a role in journalism?

VISONNEAU: Yes, it has, but in the beginning, in print journalism, emotion played a much smaller part. Then with the introduction of radio, it became more import- 
ant. The arrival of life coverage, as in sports broadcasts, sought to make the spectator tremble with excitement. Then with television, it came into full bloom. At first there was the shock of the images, and soon followed what we call in French, the micro-trottoir, interviewing the man-on-the-street. When the practice started, it was a good thing, because previously the news had been cold and institutional, and this new form of expression allowed us to measure the temperature of public opinion. After a while, however, it became a complete disaster; emotion soon began to tyrannize the news. Now with social media we have arrived at the paroxysm of emotion in full splendor.

As an example, I would like to make a short digression based on my own personal experience. In 1981 a socialist president, François Mitterand, was elected in France after 23 years of conservative rule. At the time I was editor-in-chief of a televised news broadcast in Nice and I experienced this change as a revolution. At that time the key word in journalism was change. The news, which until then had been very institutional, suddenly thrust open its doors and windows to greet life, true life itself. My team of journalists and I were very enthusiastic, but when I look back on it today, I think that even if this movement was positive at the beginning, it unfortunately went quickly to the other extreme. In 1981 in France there were only three public channels. Then suddenly with the appearance of CNN in the U.S., the landscape of television news was irrevocably altered. Several all-news stations appeared in France. Here again, it was, at first, a good development, but soon after, they became the precursors of the loss of journalistic credibility: the domination of short-form reporting (75 seconds, for example, devoted to the Middle East), loop repetition, the importance of fait divers, that is, stories of fires, shootings, natural catastrophes, etc. that became a new form of entertainment. We call it infotainment and this word is also used in French. The final stage of this evolution is to be found I the profusion of experts and pseudo-experts who are called in to comment on the events. Too many people speaking on too many different topics has the effect of reducing credibility.

CIPOLLA: Let's get back to the question of this elixir that you mentioned. After emotion, you said the next element was amplification. What do you mean by that?

VISONNEAU: This is where social media come into play. Social media provide an enormous instrument for amplification. This is in the nature of crowds and our attraction to them, but it also underscores the risks of crowd sourcing. Then there are also the panic reactions: anger, lynching, bashings etc. that come with unleashed collective emotional response. Kierkegaard warned us about this: 'the crowd is untruth while the individual is the awakening of the spirit'.

CIPOLLA: What was the third ingredient of the elixir?

VISONNEAU: Oh, yes, the third ingredient is speed. What's new here is the speed of 
transmission of the news. It also includes the number of people reached. We live in a society of speed, of the instantaneous. With their 'live-on-the-spot' coverage, the all-news stations broadcasting 24/7, and the social networks like TWITTER, INSTAGRAM, and FACEBOOK, now more than ever before, the rallying cry of the media is FASTER, FASTER, FASTER. We must remember the importance of getting it right before that of getting it first. Finally, the last point is what we call infobésité (infobesity), that is, information overload. People are surrounded by stories (Twitter, Facebook, etc.); there is no time for critical reflection. Information overload can also be a deliberate communicative strategy that could be used in news driven cyberwar. Infobesity makes it impossible to establish a hierarchy and renders analytical distance impossible. It reminds me of an old proverb: if you can't convince them, confuse them.

CIPOLLA: We understand; the elixir is a poison; fake news has infected us. Do you think that journalists can provide an antidote?

VISONNEAU: Well, it is very difficult to answer this question with any kind of certainty. The very problem of speaking about fake news is precisely, speaking of fake news! For example, if you tell me a rumor that I have never heard anything about, I am infected. Then when I pass it on, I become the next instrument of the rumor's transmission. That is why - as a journalist - it is so important to choose which fake news stories you will work against. For instance, when Trump denies climate change, it is absolutely necessary to attack him because this idea has already convinced so many believers.

CIPOLLA: Because it is so dangerous.

VISONNEAU: To give another example, a video was viewed more than one million times with the headline: Mainstream Media Does Not Want You to See This. The video showed someone, identified as an immigrant, brutally beating nurses in a hospital. In reality, this was an old video of a Russian drunk in a hospital in Siberia. And, by the way, this is a true story! One last example that is closer to us here in New York, concerns a story about Russians hacking the power system through an electrical grid in Vermont. This was an error made by the Washington Post, but it was picked up by Agence France Presse and spread throughout Europe. The British journalist Glenn Greenwald, writing in the online magazine The Intercept, commented that the story, although it might seem trivial, is important, and here I quote Greenwald, 'because it reflects the deeply irrational and ever-spiraling fever that is being cultivated in U.S. political discourse and culture about the threat posed by Moscow'.

Here I would like to make three remarks. First, the press is not exempt from error, but at least the press recognizes its mistake, corrects it and apologizes. (Trump has never made a mistake, nor has he ever apologized). Second, fake news has a viral potential six times more potent than a corrected news item. False news stories are more 
widely and more quickly shared than true ones. Third, fake news is binary while the journalist's work is more finely shaded. The criteria of like and share on Facebook do not apply to journalism. Journalism is contextualization, doubt, research, contradictory versions, all of which create subtle shades of meaning. Now this leads us to the difference between making judgements and reasoning. To judge is binary, to think is complex. The more one thinks objectively, the less one exists. In the political news class, the craze for judgement overrides far too often, the concern for understanding. Judging is quick and easy; thinking is long and tiring.

CIPOLLA: Is there any remedy for this sick state of affairs?

VISONNEAU: We must consider that we are suffering from a form of moral panic. We are living through something far more widespread than the Trump phenomenon. This is not only the shattering of the news as such, it is a global crisis of what it means to inform. We must use the arms at our disposal, and first, language. We must begin by ceasing to speak about fake news.

We should be speaking about trust rather than truth. Words, our own words, have been turned against us by those who have declared war against journalism. Trump also speaks of fake news? In reality we are experiencing a kind of conceptual bankruptcy. In all of this, social media must accept the burden of their responsibility, because, in the algorithm of Facebook, there is no objective way to speak of things. ${ }^{1}$ The loss of contact with reality, the now famous divorce of the elites from the masses haunts the press and democracy alike. Journalism is shaken to its foundation, and the morality of its practice is far from explaining the scope of the crisis. In fact, and we see this more and more clearly, the news has never had as many different demands placed on it, as many ethical codes, as many critical accusations, and all of this is for the good of the people. The news is rediscovering the virtue of taking an offensive position in interviews, of total immersion in the situation, also of humility when confronting witnesses, ordinary people who now publish their own stories themselves. The question of responsibility remains. Whose fault is all this? Could it be Truman Capote's with his non-fiction novels like In Cold Blood? Perhaps Tom Wolfe is responsible with is Bonfire of the Vanities. Or perhaps the fault is that of the philosophers: Derrida, following Nietzsche, or that gang of French Theorists that Bill says were sometimes referred to as intellectual terrorists. On this last point he may speak to you tomorrow.

New York, November 16, 2018

\footnotetext{
${ }^{1}$ Aine Kerr, former head of global journalism partnerships for Facebook.
} 
FUNDING: This research received no external funding.

CONFLICTS OF INTEREST: The authors declare no conflict of interest.

\section{BIOGRAPHICAL NOTE}

Patrick Visonneau is retired, living in Nantes, France.

William F. Cipolla is professor of International Communications at the St. John's University in New York, USA.

OPEN ACCESS: This article is distributed under the terms of the Creative Commons Attribution Non-commercial License (CC BY-NC 4.0) which permits any noncommercial use, and reproduction in any medium, provided the original author(s) and source are credited.

ARTICLE HISTORY: Received 2019-01-15 / Accepted 2019-10-16 